\title{
Receptor Binding Affinities of Synthetic Cannabinoids Determined by Non-Isotopic Receptor Binding Assay
}

\author{
Hye Jin Cha', Yun Jeong Song', Da Eun Lee', Young-Hoon Kim ', Jisoon Shin', Choon-Gon Jang', \\ Soo Kyung Suh', Sung Jin Kim ${ }^{3}$ and Jaesuk Yun ${ }^{4, \psi}$ \\ ${ }^{1}$ Pharmacological Research Division, Toxicological Evaluation and Research Department, National Institute of Food \\ and Drug Safety Evaluation, Ministry of Food and Drug Safety, Chungju, Korea \\ ${ }^{2}$ Department of Pharmacology, School of Pharmacy, Sungkyunkwan University, Suwon, Korea \\ ${ }^{3}$ Cosmetics Policy Division, Ministry of Food and Drug Safety, Chungju, Korea \\ ${ }^{4}$ Neuroimmunology Lab, College of Pharmacy, Wonkwang University, Iksan, Korea
}

\begin{abstract}
A major predictor of the efficacy of natural or synthetic cannabinoids is their binding affinity to the cannabinoid type I receptor $\left(\mathrm{CB}_{1}\right)$ in the central nervous system, as the main psychological effects of cannabinoids are achieved via binding to this receptor. Conventionally, receptor binding assays have been performed using isotopes, which are inconvenient owing to the effects of radioactivity. In the present study, the binding affinities of five cannabinoids for purified $\mathrm{CB}_{1}$ were measured using a surface plasmon resonance (SPR) technique as a putative non-isotopic receptor binding assay. Results were compared with those of a radio-isotope-labeled receptor binding assay. The representative natural cannabinoid $\Delta^{9}$-tetrahydrocannabinol and four synthetic cannabinoids, JWH- 015 , JWH210, RCS-4, and JWH-250, were assessed using both the SPR biosensor assay and the conventional isotopic receptor binding assay. The binding affinities of the test substances to $\mathrm{CB}_{1}$ were determined to be (from highest to lowest) $9.52 \times 10^{-13} \mathrm{M}(\mathrm{JWH}-210), 6.54 \times 10^{-12} \mathrm{M}(\mathrm{JWH}-250), 1.56 \times 10^{-11} \mathrm{M}\left(\Delta^{9}\right.$-tetrahydrocannabinol $), 2.75 \times$ $10^{-11} \mathrm{M}(\mathrm{RCS}-4)$, and $6.80 \times 10^{-11} \mathrm{M}(\mathrm{JWH}-015)$ using the non-isotopic method. Using the conventional isotopic receptor binding assay, the same order of affinities was observed. In conclusion, our results support the use of kinetic analysis via SPR in place of the isotopic receptor binding assay. To replace the receptor binding affinity assay with SPR techniques in routine assays, further studies for method validation will be needed in the future.
\end{abstract}

Key words: $\Delta^{9}$-THC, Human cannabinoid type I receptor $\left(\mathrm{CB}_{1}\right)$, Receptor binding assay, Surface plasmon resonance, Synthetic cannabinoids

\section{INTRODUCTION}

Synthetic cannabinoids are commonly used worldwide because they induce a euphoric effect similar to that of $\Delta^{9}$ -

Correspondence to: Hye Jin Cha, Pharmacological Research Division, Toxicological Evaluation and Research Department, National Institute of Food and Drug Safety Evaluation, Ministry of Food and Drug Safety, Chungju 28159, Korea

E-mail: chahj1@korea.kr

"Present address: Pharmacology Lab., College of Pharmacy, Chungbuk National University, Chungju, Korea

This is an Open-Access article distributed under the terms of the Creative Commons Attribution Non-Commercial License (http:// creativecommons.org/licenses/by-nc/3.0) which permits unrestricted non-commercial use, distribution, and reproduction in any medium, provided the original work is properly cited. tetrahydrocannabinol $\left(\Delta^{9}\right.$-THC), the psychoactive constituent of Cannabis sativa (1-3). Effects of synthetic cannabinoids on the central nervous system include euphoria, talkativeness, and altered visual and acoustical perception (4). There are two main reasons for the synthesis of synthetic cannabinoids: one is their potential for therapeutic use, such as in oncology (5) and emotion/behavior modulation (6); the other stems from their psychotropic effects for recreation (7). However, noticeable adverse effects of synthetic cannabinoids have been reported as well (1,812). Since new synthetic cannabinoids are emerging rapidly, it is virtually impossible to control these substances legally within appropriate time intervals using scientific evidence.

The main receptor responsible for the psychoactivity of synthetic cannabinoids, the cannabinoid type I receptor 
$\left(\mathrm{CB}_{1}\right)$, is relatively well-specified, and binding affinity to the receptor is a key factor in the relative psychoactivities of these compounds. Considering this, there have been several attempts to set up a rapid evaluation system, such as a quantitative structure-activity relationship model, in order to predict the psychoactivities of the synthetic cannabinoids, based on their binding constant values (4).

Generally, receptor binding affinities have been evaluated using conventional radio-isotope receptor binding assays. There are two typical assay formats used for the analysis of receptor-ligand interactions in screening applications: filtration and scintillation proximity assays $(13,14)$. The filtration method is not appropriate for radioligands with rapid dissociation rates (15), while the scintillation proximity assay is expensive and requires specific licenses for working with radioactive substances. In order to determine receptor binding affinities without using radioactive substances, several other methods have been employed in previous reports, such as fluorescence polarization (16) and time-resolved fluorescence (17).

Surface plasmon resonance (SPR) allows for the realtime monitoring of association and dissociation events between a binding partner that is immobilized on a sensor surface and one that is injected over the surface $(18,19)$. This technique is widely used to investigate many surface characteristics, such as ligand-receptor binding affinities and antigen-antibody interactions. Based on this, the SPR technique was used in the present study to investigate its utility in determining the receptor binding affinities of natural and synthetic cannabinoids $\left(\Delta^{9}\right.$-THC, JWH-210, JWH250, JWH-015, and RCS-4).

\section{MATERIALS AND METHODS}

Substances. $\quad \Delta^{9}$-THC, JWH-210, JWH-250, JWH-015, and RCS-4 chemical structures are shown in Fig. 1. All cannabinoids were purchased from Cayman Chemical (Ann Arbor, MI, USA), and [ $\left.{ }^{3} \mathrm{H}\right] \mathrm{SR} 141716 \mathrm{~A}$ was pur- chased from PerkinElmer (Waltham, MA, USA) for the receptor binding affinity assay. For vector construction and yeast transformation, the commercially synthesized $\mathrm{CB}_{1}$ gene and the pPICZ $\alpha \mathrm{C}$ vector, suitable for gene expression in yeast cells, were purchased from Bioneer Corporation (Daejeon, Korea). Restriction enzymes (EcoRI and $X b a \mathrm{I})$ were purchased from New England BioLabs, Inc. (Ipswich, MA, USA), and ligase (T4) was obtained from Promega Corporation (Madison, WI, USA). Competent cells from Escherichia coli strain DH5 $\alpha$ and Pichia pastoris strain X-33 were purchased from Invitrogen (Carlsbad, CA, USA). In order to confirm the transformation results, Anti-His(C-terminal)-HRP antibody (Invitrogen) and AntiFLAG(N-terminal) M2 antibody (Sigma-Aldrich, St. Louis, MO, USA) were used.

Vector construction and transformation. The commercially synthesized $\mathrm{CB}_{1}$ gene was amplified by PCR. The primer sequences were 5'-GAATTCGATTACAAGGATGACGACCA-3' (forward) and 5'-TCTAGACAGAGCCTCGGCAGACG-3' (reverse). The amplified $\mathrm{CB}_{1}$ gene fragment was inserted into the $\mathrm{PPICZ} \alpha \mathrm{C}$ vector with a FLAG tag at its N-terminal and His tag at its C-terminal sites, using the restriction enzymes EcoRI and $X b a \mathrm{I}$ and T4 ligase. Recombinant plasmids were transformed into $E$. coli $\mathrm{DH} 5 \alpha$ cells by heat shock $\left(42^{\circ} \mathrm{C}, 90 \mathrm{sec}\right)$, and cells were cultivated in zeocin-treated media at $37^{\circ} \mathrm{C}$ to select transformed colonies. Transformants were collected, and the inserted $\mathrm{CB}_{1}$ gene sequence was identified by a qualified sequencing agency (Bioneer Corporation).

The pPICZ $\alpha \mathrm{C}-\mathrm{CB}_{1}$ construct was linearized by restriction digestion at the $\mathrm{SacI}$ site to transform competent cells from the $P$. pastoris $\mathrm{X}-33$ strain with the $\mathrm{CB}_{1}$ gene. Transformation into the competent yeast cells was performed by heat shock $\left(42^{\circ} \mathrm{C}, 10 \mathrm{~min}\right)$. Transformed cells were incubated in zeocin-supplemented yeast peptone dextrose medium for 3 days at $28^{\circ} \mathrm{C}$. Then, transformants with the $\mathrm{Mut}^{+}$phenotype were selected in medium provided by the

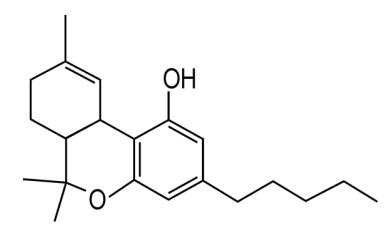

$\Delta^{9}$-THC

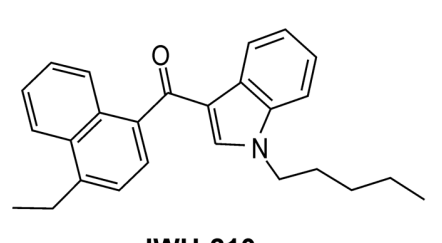

JWH-210

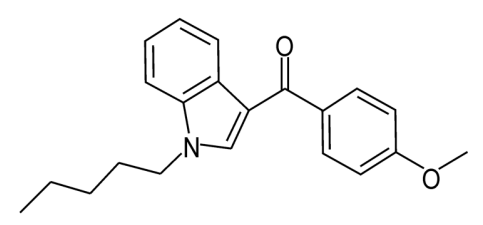

RCS-4

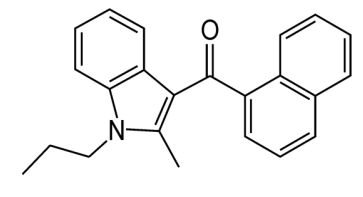

JWH-015

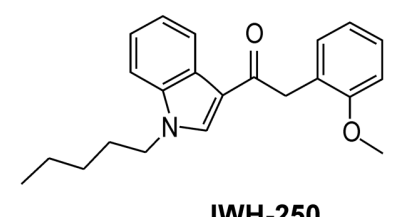

JWH-250

Fig. 1. Chemical structures of $\Delta^{9}$-tetrahydrocannabinol ( $\left.\Delta^{9}-\mathrm{THC}\right), \mathrm{JWH}-210, \mathrm{RCS}-4, \mathrm{JWH}-015$, and JWH-250. 
manufacturer (Invitrogen), and the size of the insert was verified by PCR amplification. Transformants harboring the $\mathrm{CB}_{1}$ gene were cultivated in buffered glycerol complex medium with different methanol contents $(0.5 \%$ or $1 \%)$ for various lengths of time $(0-72 \mathrm{~h})$ to determine the optimal conditions for $\mathrm{CB}_{1}$ protein induction. Protein expression levels were assessed and confirmed from the supernatant before purification using western blot with anti-FLAG (primary) and anti-mouse (secondary) antibodies.

Expressed protein was extracted from the yeast cells and purified by affinity chromatography using metal-chelated affinity and gel filtration chromatography (Superdex 16/60 S-200, GE Healthcare, Buckinghamshire, UK). The purified protein was identified using western blot in the same procedure with the same antibodies mentioned above, and the concentrated protein was stored at $-80^{\circ} \mathrm{C}$.

Receptor binding assay using SPR. A Biacore 3000 (GE Healthcare) was used to measure the binding affinities of synthetic cannabinoids and $\Delta^{9}$-THC to the recombinant $\mathrm{CB}_{1}$. Before measuring the binding affinities of the test substances, the equipment was validated using the Biacore 3000 Getting Started Kit, provided by the manufacturer. The SPR experiment was conducted in three steps: immobilization, interaction analysis, and regeneration. For immobilization, the synthesized $\mathrm{CB}_{1}$ protein was bound to the biosensor chip, CM5 (with carboxymethylated dextran attached to the gold surface), by amine coupling ( 30 $\mu \mathrm{g} / \mathrm{mL}$ concentration at $10 \mu \mathrm{L} / \mathrm{min}$ flow rate) under various $\mathrm{pH}$ conditions $(\mathrm{pH} 4.0,4.5,5.0$, and 5.5), in order to determine the optimal immobilization conditions. The injection time was $7 \mathrm{~min}$. Excess receptor was washed out with $1 \mathrm{M}$ ethanolamine- $\mathrm{HCl}(\mathrm{pH} 8.5)$. For interaction analysis, test substances $\left(\Delta^{9}\right.$-THC, JWH-210, JWH-250, JWH015 , and RCS-4) were dissolved in $100 \%$ ethanol and then diluted to $50 \mu \mathrm{M}$ with running buffer $(1 \times$ PBS : ethanol : Tween $80=19: 0.5: 0.5)$. Diluted test substances flowed into the biosensor chip at a flow rate of $50 \mu \mathrm{L} / \mathrm{min}$ for more than $5 \mathrm{~min}$, to bind to the immobilized $\mathrm{CB}_{1}$ [final amount: 2,000 response units (RU)]. For regeneration, after determining the responses, the biosensor chip was regenerated with $50 \mu \mathrm{L} / \mathrm{mL}$ running buffer for $10 \mathrm{~min}$.

The experiment was repeated at least three times, and association constants were automatically calculated from the specific binding values using BIAevaluation software (GE Healthcare) with the following formula: $\mathrm{K}_{\mathrm{a}}=\mathrm{IC}_{50} /$ $\left[1+\left([\mathrm{L}] / \mathrm{K}_{\mathrm{d}}\right)\right]$, where $\mathrm{IC}_{50}$ is the half-maximal inhibitory concentration, $[\mathrm{L}]$ is the concentration of the ligands, and $\mathrm{K}_{\mathrm{d}}$ is the equilibrium dissociation constant. The data were analyzed using Sigmaplot (Systat Software Inc., CA, USA).

Receptor binding assay using radioactive isotopes. Chemiscreen recombinant human $\mathrm{CB}_{1}$ membrane preparation (EMD Millipore Corp., Milford, MA, USA) was pur- chased and stored at $-70^{\circ} \mathrm{C}$ until use. A saturation binding assay was conducted with CP-55940, an agonist, and radioactive $\left[{ }^{3} \mathrm{H}\right] \mathrm{SR} 141716 \mathrm{~A}$, an antagonist, based on a previous report (20). Briefly, binding buffer [50 mM HEPES (pH 7.4), $5 \mathrm{mM} \mathrm{MgCl}, 1 \mathrm{mM} \mathrm{CaCl}_{2}$, and $\left.0.2 \% \mathrm{BSA}\right]$ and washing buffer [50 mM HEPES (pH 7.4), $500 \mathrm{mM} \mathrm{NaCl}$, and $0.1 \%$ BSA] were prepared and stored at $4{ }^{\circ} \mathrm{C}$ until use. The binding buffer, DMSO (15\%), and radioactive ligand $(10 \%)$ were mixed and incubated at $30^{\circ} \mathrm{C}$ for $1 \mathrm{hr}$ for the membrane binding reaction. After washing, the counts per minute (cpm) of each binding group were determined using a beta-scintillation counter. The receptor density $\left(\mathrm{B}_{\max }\right)$ and radioligand equilibrium dissociation constant $\left(\mathrm{K}_{\mathrm{d}}\right)$ values were calculated from the specific binding cpm values using GraphPad Prism 5 software (GraphPad Software, La Jolla, CA, USA).

The competition receptor binding assay was performed using a protocol similar to that of the saturation binding assay described above. The amount of specifically bound radiolabeled compound, in the absence of competing compounds, was calculated by subtracting non-specific binding from total binding: specific binding $=$ minimum specific binding $+[$ (maximum specific binding + minimum specific binding $) /\left(1+10^{\log x-\log (\text { IC50) }}\right)$ where $\mathrm{x}$ is the concentration of the tested synthetic cannabinoid]. The percentage of specific binding was calculated for the amount of radiolabeled compound bound in the presence of various concentrations of each competing compound. The data were

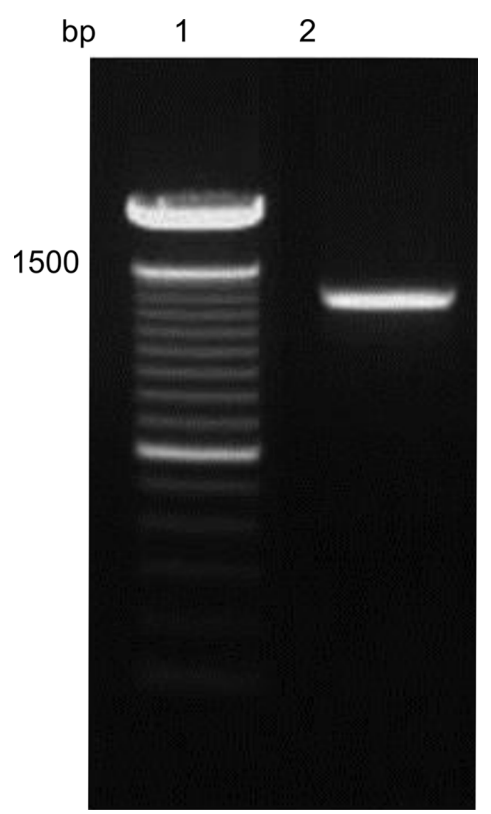

Fig. 2. $\mathrm{CB}_{1}$ gene identification by $\mathrm{PCR}$ after transformation into Pichia pastoris. Lane 1: size marker, lane 2: transformed $\mathrm{pPICZ} \alpha \mathrm{C}-\mathrm{CB}_{1}$. The gene was analyzed after selection on minimal methanol histidine and minimal methanol dextrose media. The $C_{1}$ gene size is $1,416 \mathrm{bp}$. 
analyzed with GraphPad Prism software, and the $\mathrm{IC}_{50}$ and inhibition constant $\left(\mathrm{K}_{\mathrm{i}}\right)$ values were calculated.

\section{RESULTS}

$C B_{1}$ protein expression and purification. Recombinant $\mathrm{CB}_{1}$ protein was used to measure the binding affinities of $\Delta \Delta^{9}$-THC and four synthetic cannabinoids. A commercially synthesized $\mathrm{CB}_{1}$ gene was inserted into the $\mathrm{pPICZ} \alpha \mathrm{C}$ vector and used to transform E. coli $\mathrm{DH} 5 \alpha$ cells. Transformants with zeocin resistance were selected, and inserted genes were sequenced in order to verify the $\mathrm{CB}_{1}$ gene insertion in the $\mathrm{pPICZ} \alpha \mathrm{C}$ vector. The $\mathrm{CB}_{1}$ sequence was determined by a professional company and was verified using the NCBI Blast database (Fig. 2). The cloned gene was then used to transform yeast cells (P. pastoris X-33)
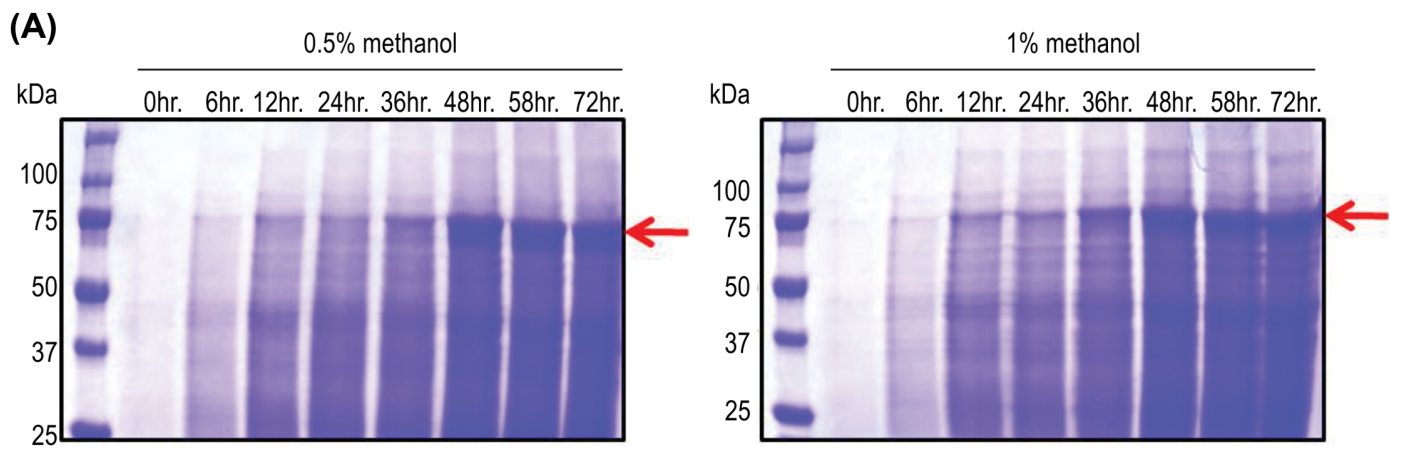

(B)

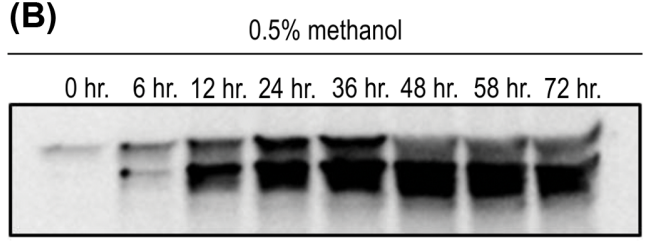

(C)
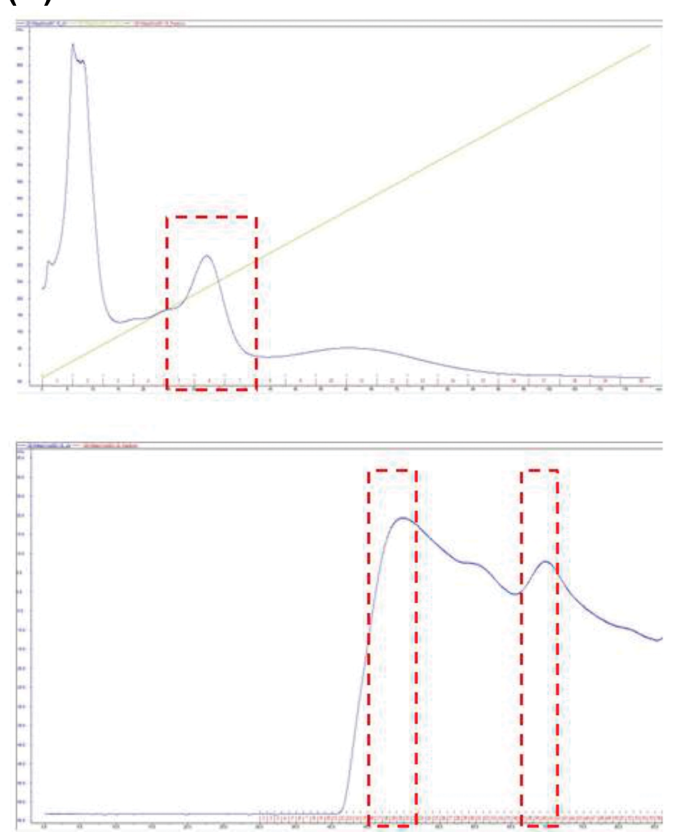

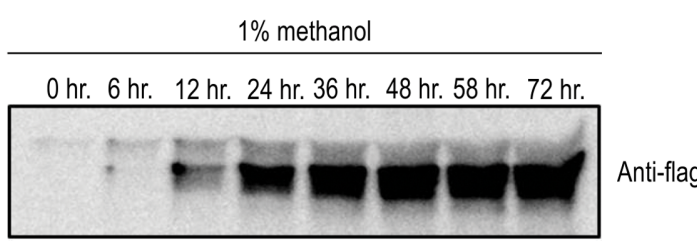

$1^{\text {st }}$ : Anti-flag $(1: 1000)$

$2^{\text {nd. }}$ : Anti-mouse (1:1000)
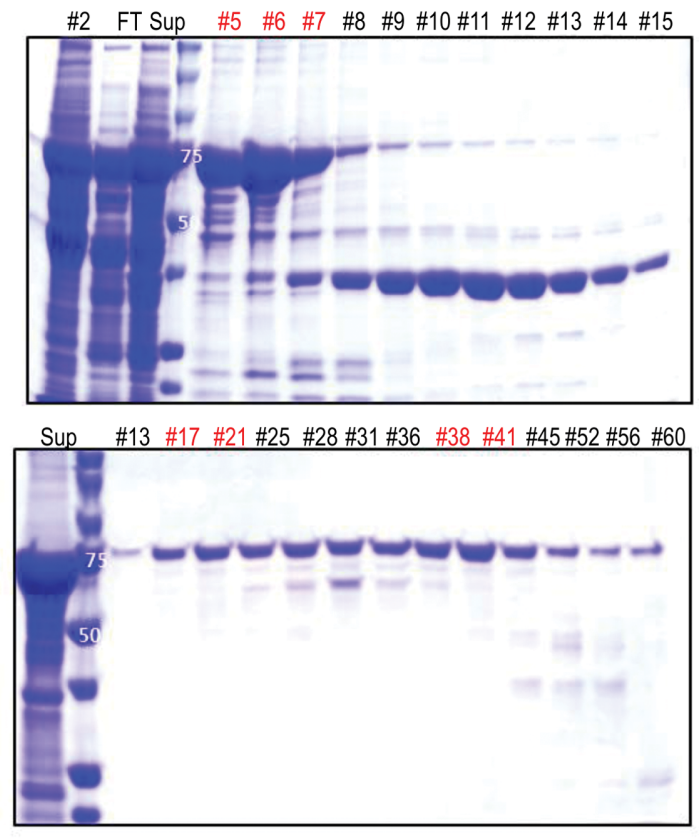

Fig. 3. Expression levels of $\mathrm{CB}_{1}$ protein in Pichia pastoris. Expressed proteins were analyzed over time at various methanol concentrations ( 0.5 and $1.0 \%)$. Expressed protein level was determined by (A) Coomassie blue staining and (B) western blot. (C) The protein was purified using a Ni-column (upper panels, number: fraction number, FT: flow-through, Sup: supernatant, lane 4: size marker) and gel chromatography (lower panels, Sup: supernatant, lane 2: size marker, number: fraction number). The $\mathrm{CB}_{1}$ protein size is $75 \mathrm{kDa}$. 
for expression of $\mathrm{CB}_{1}$ protein. The $\mathrm{CB}_{1}$ gene in the yeast transformants was confirmed to be $1,416 \mathrm{bp}$ using PCR in order to verify the correct insertion of the target gene into the yeast competent cells. Based on Coomassie blue staining and western blot of $\mathrm{CB}_{1}$ protein, the protein was expressed beginning at $12 \mathrm{hr}$, with maximal expression after 48,58 , and $72 \mathrm{hr}$ of cultivation with $1 \%$ methanol
(Fig. 3A, 3B). After the purification process (chromatography with Ni-chelated affinity column and gel filtration), $5.6 \mathrm{mg}$ of $\mathrm{CB}_{1}$ protein was obtained (Fig. 3C).

Receptor binding assay using SPR. The optimal $\mathrm{pH}$ for immobilizing the synthesized $\mathrm{CB}_{1}$ protein was 5.0. As shown in Fig. 4, the $\mathrm{CB}_{1}$ protein was bound to the biosen-

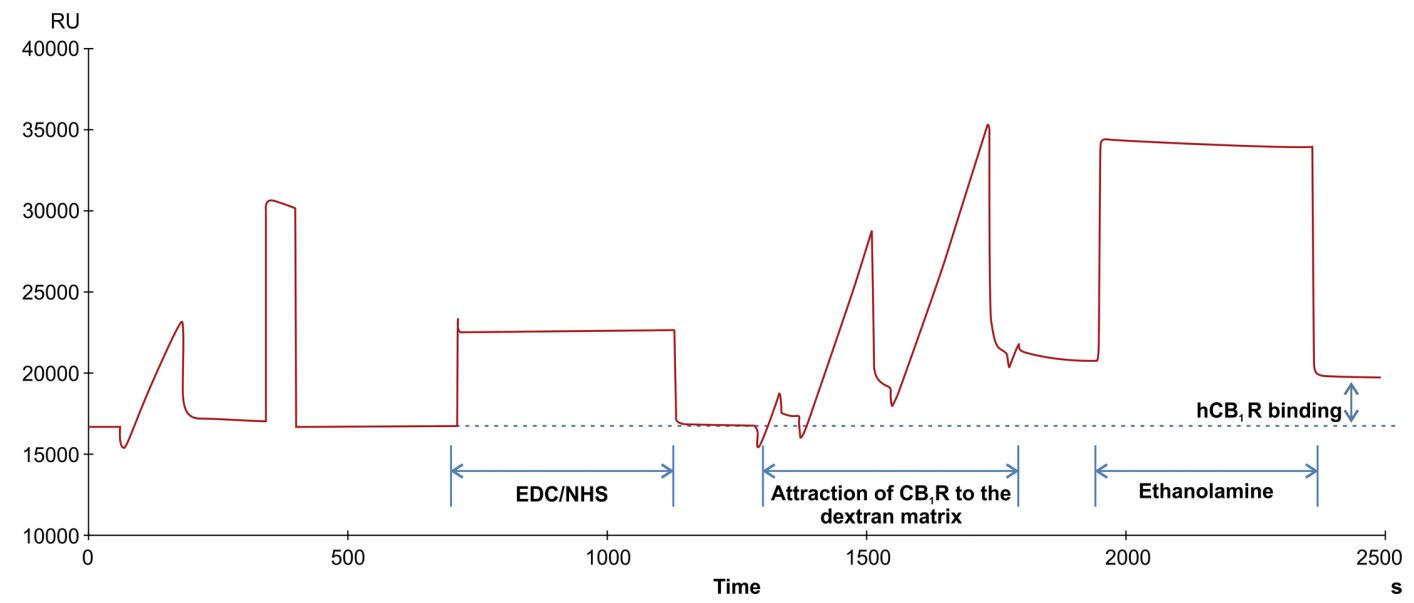

Fig. 4. Immobilization of $\mathrm{CB}_{1}$ on the biosensor chip (CM5) by amine coupling. $\mathrm{EDC}$ [0.4 M 1-ethyl-3-(3-dimethylaminopropyl)-carbodiimide] and NHS (0.1 M N-hydroxysuccinimide) coupling solution was used to activate the $\mathrm{CM} 5$ chip. $\mathrm{CB}_{1}$ protein was diluted in sodium acetate buffer ( $\mathrm{pH} \mathrm{5.0)}$ and flowed into the biosensor chip at $10 \mu \mathrm{L} / \mathrm{min}$ for $7 \mathrm{~min}$. Uncoupled protein was washed out by $1 \mathrm{M}$ ethanolamine- $\mathrm{HCl}(\mathrm{pH}$ 8.5). Proteins were coated at 2,000 response units (RU).
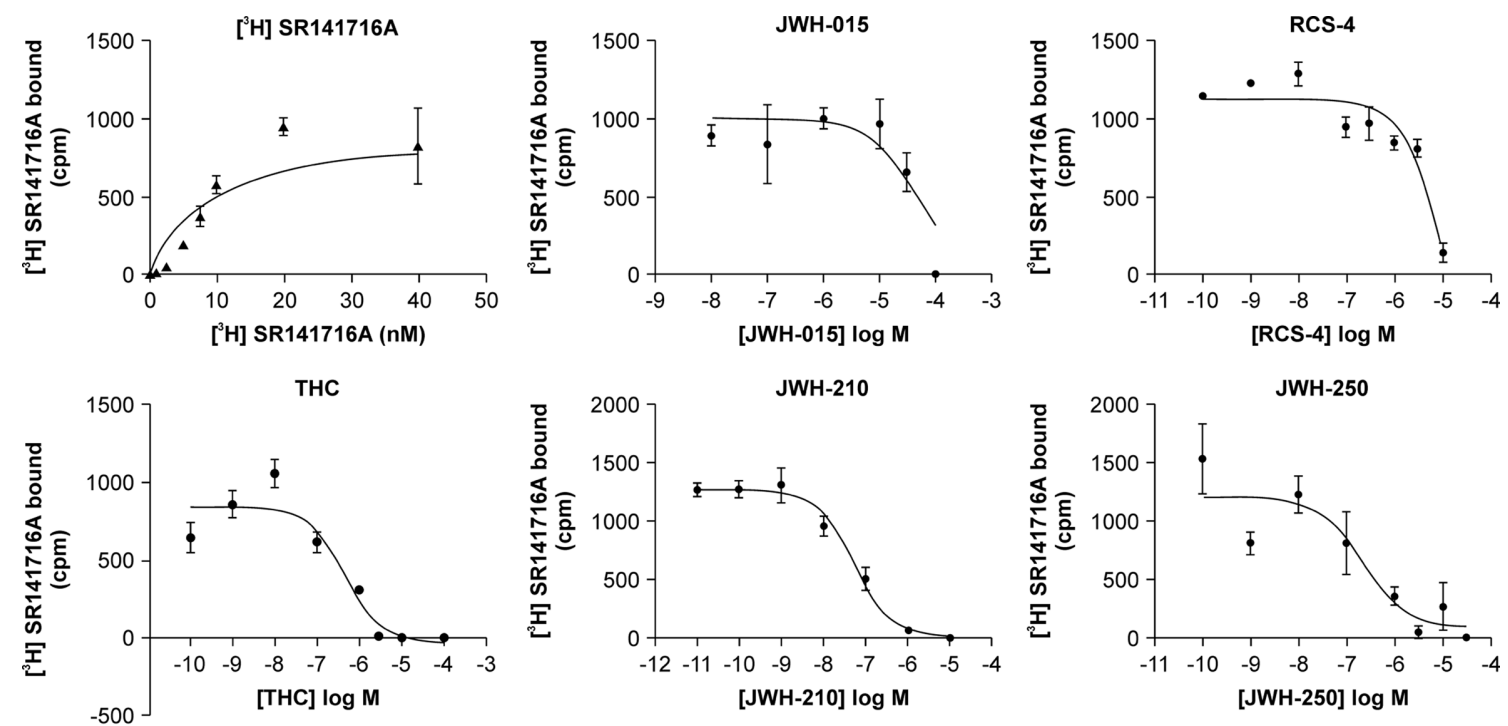

\begin{tabular}{|c|c|c|c|c|c|}
\hline & JWH-210 & JWH-250 & $\Delta^{9}-\mathrm{THC}$ & RCS-4 & JWH-015 \\
\hline $\mathrm{IC}_{50}(\mathrm{M})$ & $5.3 \times 10^{-8}$ & $2.1 \times 10^{-7}$ & $4.7 \times 10^{-7}$ & $1.5 \times 10^{-5}$ & $4.7 \times 10^{-5}$ \\
\hline $\mathrm{K}_{i}(\mathrm{M})$ & $2.6 \times 10^{-8}$ & $1.1 \times 10^{-7}$ & $2.3 \times 10^{-7}$ & $7.3 \times 10^{-6}$ & $2.3 \times 10^{-5}$ \\
\hline
\end{tabular}

Fig. 5. $C B_{1}$ binding affinities of $\Delta^{9}-T H C$, JWH-210, JWH-250, JWH-015, and RCS-4 using SPR equipment. The binding affinities were measured in real time, and the test was repeated six times. The order of receptor binding affinity from highest to lowest was JWH210, JWH-250, $\Delta^{9}$-THC, RCS-4, and JWH-015. 


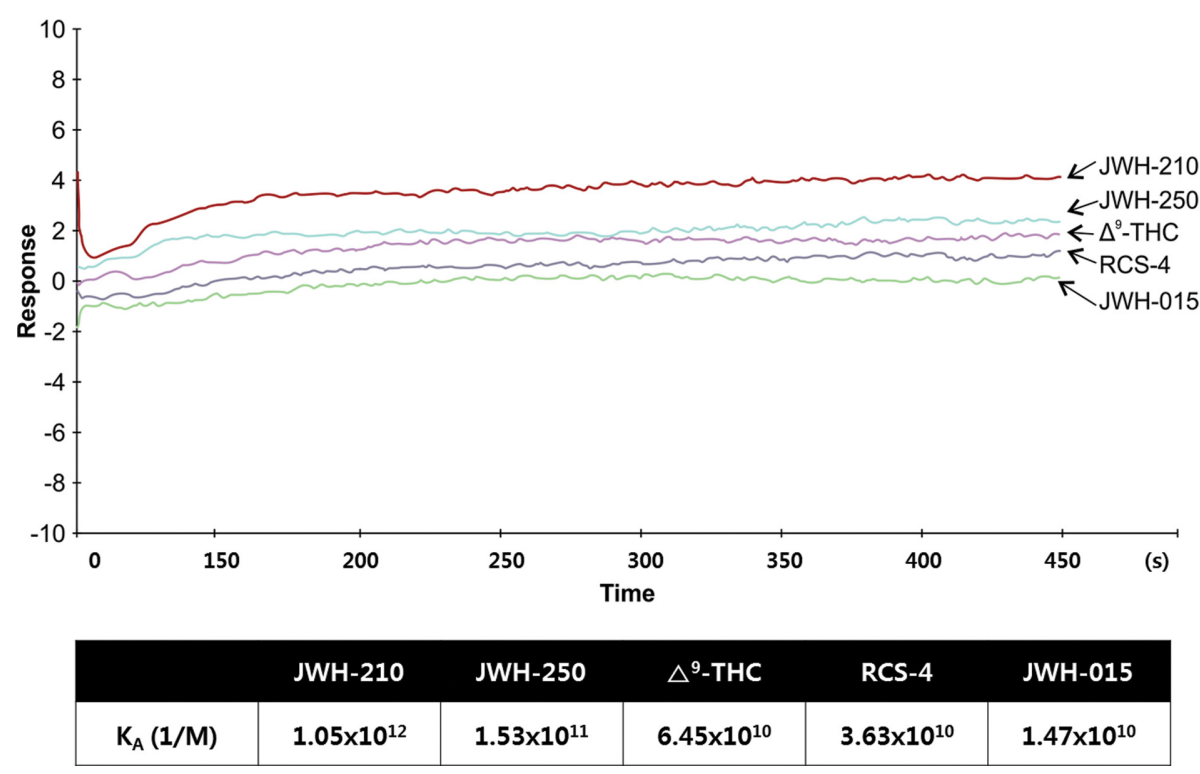

Fig. 6. Competitive binding curves for $\Delta^{9}-\mathrm{THC}$, JWH-210, JWH-250, JWH- 015 , and RCS-4 to $\mathrm{CB}_{1}$ over-expressing cell membranes using the conventional isotopic receptor binding assay. Data are means \pm standard errors.

sor chip at 2,000 RU. The $\mathrm{K}_{\mathrm{a}}$ values of $\Delta^{9}$-THC, JWH210, JWH-250, JWH-015, and RCS-4 were $6.45 \times 10^{10} \mathrm{M}^{-1}$, $1.05 \times 10^{12} \mathrm{M}^{-1}, 1.53 \times 10^{11} \mathrm{M}^{-1}, 1.47 \times 10^{10} \mathrm{M}^{-1}$, and $3.63 \times$ $10^{10} \mathrm{M}^{-1}$, respectively. The sensorgram for the test substances is depicted in Fig. 5. The highest receptor binding affinity was exhibited by JWH-210, followed by JWH250, $\Delta^{9}$-THC, RCS-4, and lastly JWH-015.

Receptor binding assay with radioactive isotopes. The $\mathrm{CB}_{1}$ binding affinity of $\Delta^{9}$-THC, JWH-210, JWH-250, JWH-015, and RCS-4 was measured by saturation binding and competitive binding assays using over-expressed protein membranes. In the saturation binding assay with $\left[{ }^{3} \mathrm{H}\right] \mathrm{SR} 141716 \mathrm{~A}$, the $\mathrm{B}_{\max }$ was $953 \mathrm{cpm}$ and the $\mathrm{K}_{\mathrm{d}}$ value was $8.768 \mathrm{nM}$. The $\mathrm{IC}_{50}$ values and $\mathrm{K}_{\mathrm{i}}$ values of the test substances were calculated using the results of the competitive binding assay and the $\mathrm{B}_{\max }$ and $\mathrm{K}_{\mathrm{d}}$ values. The $\mathrm{IC}_{50}$ values of $\Delta^{9}$-THC, JWH-210, JWH-250, JWH-015, and RCS-4 were $4.7 \times 10^{-7} \mathrm{M}, 5.8 \times 10^{-8} \mathrm{M}, 2.1 \times 10^{-7} \mathrm{M}, 4.7 \times$ $10^{-5} \mathrm{M}$, and $1.5 \times 10^{-5} \mathrm{M}$, respectively, and the $\mathrm{K}_{\mathrm{i}}$ values were $2.3 \times 10^{-7} \mathrm{M}, 2.6 \times 10^{-8} \mathrm{M}, 1.1 \times 10^{-7} \mathrm{M}, 2.3 \times 10^{-5} \mathrm{M}$, and $7.3 \times 10^{-6} \mathrm{M}$, respectively. The highest binding affinity to $\mathrm{CB}_{1}$ of the test substances was exhibited by JWH210 , followed by JWH-250, $\Delta^{9}-\mathrm{THC}, \mathrm{RCS}-4$, and finally JWH-015. The order of the $\mathrm{CB}_{1}$ binding affinities of the test substances was therefore the same as that determined using the non-isotopic receptor binding assay. The saturation and competitive binding curves are shown in Fig. 6.

\section{DISCUSSION}

Synthetic cannabinoids have caused social issues in
Korea since 2010 because of their marijuana-like effects, such as euphoria (20). As the Ministry of Food and Drug Safety is charged with designating controlled substance status to new psychoactive substances, it is necessary to evaluate the dependence liabilities of synthetic cannabinoids in order to regulate the substances as either "psychoactive drugs" or "temporary psychoactive substances", based on the "Act on the Control of Narcotics."

In the present study, an in vitro receptor binding assay was performed using SPR and compared to the isotopic receptor binding assay, in order to establish a reliable and safe evaluation system to predict the psychoactivities of synthetic cannabinoids. There have been several previous attempts to create an in silico prediction model of synthetic cannabinoids $(4,21,22)$. In order to establish an in silico prediction model, the collection of in vivo or in vitro data, such as the $50 \%$ maximal effective dose $\left(\mathrm{ED}_{50}\right)$ or pharmacodynamical values $\left(\mathrm{K}_{\mathrm{a}}, \mathrm{K}_{\mathrm{d}}, \mathrm{K}_{\mathrm{i}}\right)$, is essential. However, since in vivo experiments are time-, labor-, and costintensive compared to in vitro assays, it would be more efficient to set up an in vitro assay system to obtain the relevant data for an in silico prediction model.

In vitro receptor binding assays can be tools for dependence prediction of emerging substances, especially when the target receptors are well defined. In our previous study, the receptor binding affinity and the in vivo dependence potential were revealed to be correlated with each other (20). As an in vitro method, receptor binding assays have conventionally been performed using radioisotopes $(13,14)$, which offer many disadvantages in terms of the handling of radioactive substances. Since the SPR technique does not need radioactive ligands, it would be beneficial for 
user safety. In this regard, the SPR technique was employed to measure the receptor binding affinities of synthetic cannabinoids, in order to create a non-isotopic method for dependence potential prediction. The SPR technique uses biosensors, an analytical system that combines biological recognition and transduction into an electrical signal. Biosensor-based methods are powerful approaches for the monitoring of molecular binding activity $(18,19)$. Through the SPR technique, it is possible to detect binding affinities in real time.

Transmembrane proteins are generally known to be difficult to express and purify. Since most receptors for chemicals, including $\mathrm{CB}_{1}$, are transmembrane proteins, the availability of receptors is highly limited. To overcome this limitation, $\mathrm{CB}_{1}$ protein was expressed and purified using E. coli and P. pastoris, respectively, in order to develop a receptor protein expression and purification system. Traditionally, E. coli has been commonly used for the replication of various genes owing to its advantageous characteristics in terms of practicality and economic feasibility. However, it is not appropriate for post-translational expression of proteins because it lacks many endoplasmic organelles essential for substantive protein expression. In this regard, a methylotrophic yeast strain, P. pastoris, has been used in several reports $(23,24)$. According to these reports, a methylotrophic yeast strain is useful for cloning eukaryotic genes, as yeast is a eukaryote possessing an endoplasmic system for post-translational modifications. Expression of $\mathrm{CB}_{1}$ using both $E$. coli and $P$. pastoris was introduced in a previous report that demonstrated the efficiency of using a FLAG tag at the N-terminus and c-Myc and hexahistidine tags at the C-terminus (25). However, the authors could not demonstrate ligand binding with the purified $\mathrm{CB}_{1}$ in their study. This was suggested to be due to the environmental sensitivity of $\mathrm{CB}_{1}$. Considering this suggestion, in the present study, $\mathrm{CB}_{1}$ was purified using a nickel-charged column and gel filtration and was confirmed to be successfully bound to the biosensor chip of the SPR. This is the first study to report cloned $\mathrm{CB}_{1}$ with the ability to act as a ligand-binding receptor.

In order to validate the established non-isotopic receptor binding assay method for rapid dependence prediction in the present study, the data on synthetic cannabinoids from the SPR receptor binding assay were compared to those from the conventional isotopic filtration receptor binding assay. The results from the non-isotopic and conventional isotopic methods were in accordance to each other, namely that the highest binding affinity was exhibited by JWH-210, followed by JWH-250, $\Delta^{9}$-THC, RCS-4, and JWH-015.

There have been several reports on the relationship between in vivo psychoactivity and cannabinoid receptor binding affinity (26-28). With the exception of the study by Presley et al. (26), these studies used radio-ligands for measuring receptor binding affinities. Wiley et al. (28) compared the in vivo THC-like effects of three synthetic cannabinoids with their in vitro $\mathrm{CB}_{1}$ binding affinities, using the filtration method and agonist-stimulated $\left[{ }^{35} \mathrm{~S}\right] \mathrm{GTP} \gamma \mathrm{S}$ binding affinities, indicating the close association of the in vitro binding affinities with behavioral activities. Smoum et al. (27) also suggested the availability of receptor binding affinities of synthetic cannabinoids with the biological potencies of cannabinoid receptor agonists. Presley et al. (26) applied the ACTOne assay, which had been used for G-protein coupled receptor pharmacology, in order to establish a new pharmacological evaluation system using $\mathrm{CB}_{1}$ signaling in endocannabinoids and synthetic cannabinoids. They compared the ACTOne assay with several conventional receptor binding assays, such as the $\left[{ }^{35} \mathrm{~S}\right] \mathrm{GTP} \gamma \mathrm{S}, \beta$ arrestin, and cAMP assays, and recommended the ACTOne assay as a high-throughput evaluation method. This suggested system has not been sufficiently validated yet, but it provides useful information. In addition, a previous in vivo behavioral pharmacological study showed that the rewarding effect of JWH-210 was higher than that of $\Delta^{9}$ THC (29). The binding affinity of the present study is in line with this result, suggesting the in vitro SPR assay would be useful to predict the psychoactivity of unknown substances.

A limitation of our study is the relatively small number of tested synthetic cannabinoids. Prior to applying the established non-isotopic receptor binding assay, data on more synthetic cannabinoids from further studies is needed to enhance its predictivity and accuracy. As attempts are also being made to synthesize new recreational substances, additional studies are also needed to establish the use of this method in evaluating other groups of new psychoactive substances, such as synthetic cathinones and amphetamine-type stimulators. Taken together, our findings indicate that the established non-isotopic receptor binding assay involving the SPR method has the potential to be useful for the prediction of dependence liabilities of synthetic cannabinoids in the future.

\section{ACKNOWLEDGMENTS}

This work was supported by the National Institution of Food and Drug Safety Evaluation/Ministry of Food and Drug Safety (14181MFDS503).

\section{CONFLICT OF INTEREST}

The authors declare that the research was conducted in the absence of any commercial or financial relationships that could be construed as a potential conflict of interest.

Received May 23, 2018; Revised August 7, 2018; Accepted August 21, 2018 


\section{REFERENCES}

1. Karila, L., Benyaminia, A., Blecha, L., Cottencin, O. and Billieux, J. (2016) The synthetic cannabinoids phenomenon. Curr. Pharm. Des., 22, 6420-6425.

2. Scocard, A., Benyamina, A., Coscas, S. and Karila, L. (2017) Synthetic cannabinoids: A new addiction matrix. Pres. Méd., 46, 11-22.

3. Tournebize, J., Gibaja, V. and Kahn, J.P. (2016) Acute effects of synthetic cannabinoids: update 2015. Subst. Abuse, 11, 1-23.

4. Paulke, A., Proschak, E., Sommer, K., Achenbach, J., Wunder, C. and Toennes, S.W. (2016) Synthetic cannabinoids: In silico prediction of the cannabinoid receptor 1 affinity by a quantitative structure-activity relationship model. Toxicol. Lett., 245, 1-6.

5. Maida, V. and Daeninck, P.J. (2016) A user's guide to cannabinoid therapies in oncology. Curr. Oncol., 23, 398-406.

6. Androvicova, R., Horacek, J., Stark, T., Drago, F. and Micale, V. (2017) Endocannabinoid system in sexual motivational processes: Is it a novel therapeutic horizon? Pharmacol. Res., 115, 200-208.

7. Ford, B.M., Tai, S., Fantegrossi, W.E. and Prather, P.L. (2017) Synthetic pot: not your grandfather's marijuana. Trend. Pharmacol. Sci., 38, 257-276.

8. Cooper, Z.D. (2016) Adverse effects of synthetic cannabinoids: management of acute toxicity and withdrawal. Curr. Psych. Rep., 18, 52.

9. Fattore, L. (2016) Synthetic cannabinoids - Further evidence supporting the relationship between cannabinoids and psychosis. Biol. Psych., 79, 539-548.

10. Gray, R., Bressington, D., Hughes, E. and Ivanecka, A. (2016) A systematic review of the effects of novel psychoactive substances 'legal highs' on people with severe mental illness. J. Psych. Ment. Health Nurs., 23, 267-281.

11. Springer, Y.P., Gerona, R., Scheunemann, E., Shafer, S.L., Lin, T., Banister, S.D. and McLaughlin, J.B. (2016) Increase in adverse reactions associated with use of synthetic cannabinoids - Anchorage, Alaska, 2015-2016. MMWR Morb. Mort. Wkly Rep., 65, 1108-1111.

12. White, C.M. (2017) The pharmacologic and clinical effects of illicit synthetic cannabinoids. J. Clin. Pharmacol., 57, 297-304.

13. Diez-Alarcia, R., Ibarra-Lecue, I., Lopez-Cardona, A.P., Meana, J., Gutierrez-Adan, A., Callado, L.F. and Uriguen, L. (2016) Biased agonism of three different cannabinoid receptor agonists in mouse brain cortex. Front. Pharmacol., 7, 415.

14. McPartland, J.M., Glass, M. and Pertwee, R.G. (2007) Metaanalysis of cannabinoid ligand binding affinity and receptor distribution: interspecies differences. Br. J. Pharmacol., 152, 583-593.

15. Layer, R.T. (2001) Saturation analysis of ligand binding using a centrifugation procedure. Curr. Protoc. Neurosci., 2, 7.7.1-7.7.4.

16. Rossi, A.M. and Taylor, C.W. (2013) High-throughput fluorescence polarization assay of ligand binding to $\mathrm{IP}_{3}$ receptors. Cold Spring Harb. Prot., 2013, 938-946.

17. Martinez-Pinilla, E., Rabal, O., Reyes-Resina, I., Zamar- bide, M., Navarro, G., Sanchez-Arias, J.A. and Franco, R. (2016) Two affinity sites of the cannabinoid subtype 2 receptor identified by a novel homogeneous binding assay. $J$. Pharmacol. Exp. Ther., 358, 580-587.

18. Hoa, X.D., Kirk, A.G. and Tabrizian, M. (2007) Towards integrated and sensitive surface plasmon resonance biosensors: a review of recent progress. Biosens. Bioelectron., 23, 151-160.

19. Piliarik, M., Vaisocherova, H. and Homola, J. (2009) Surface plasmon resonance biosensing. Methods Mol. Biol., 503, 65-88.

20. Cha, H.J., Lee, K., Song, M., Hyeon, Y., Hwang, J., Jang, C. and Jeong, H. (2014) Dependence potential of the synthetic cannabinoids JWH-073, JWH-081, and JWH-210: In vivo and in vitro approaches. Biomol. Ther. (Seoul), 22, 363-369.

21. Mella-Raipan, J., Hernandez-Pino, S., Morales-Verdejo, C. and Pessoa-Mahana, D. (2014) 3D-QSAR/CoMFA-based structure-affinity/selectivity relationships of aminoalkylindoles in the cannabinol $\mathrm{CB}_{1}$ and $\mathrm{CB}_{2}$ receptors. Molecules, 19, 2842-2861.

22. Myint, K.Z. and Xie, X.Q. (2015) Ligand biological activity predictions using fingerprint-based artificial neural networks (FANN-QSAR). Methods Mol. Biol., 1260, 149-164.

23. Cereghino, J.L. and Cregg, J.M. (2000) Heterologous protein expression in the methylotrophic yeast Pichia pastoris. FEMS Microbiol. Rev., 24, 45-66.

24. Reilander, H. and Weiss, H.M. (1998) Production of G-protein-coupled receptors in yeast. Curr. Opin. Biotechnol., 9, 510-517.

25. Kim, T.K., Zhang, R., Feng, W., Cai, J., Pierce, W. and Song, Z.H. (2005) Expression and characterization of human $\mathrm{CB}_{1}$ cannabinoid receptor in methylotrophic yeast Pichia pastoris. Protein. Expr. Purif., 40, 60-70.

26. Presley, C.S., Abidi, A.H. and Moore, B.M., 2nd. (2016) Cannabinoid receptor 1 ligands revisited: Pharmacological assessment in the ACTOne system. Anal. Biochem., 498, 828.

27. Smoum, R., Baraghithy, S., Chourasia, M., Breuer, A., Mussai, N., Nttar-Namdar, M. and Bab, I. (2015) $\mathrm{CB}_{2}$ cannabinoid receptor agonist enantiomers HU-433 and HU-308: An inverse relationship between binding affinity and biological potency. Proc. Natl. Acad. Sci. U.S.A., 112, 8774-8779.

28. Wiley, J.L., Marusich, J.A., Lefever, T.W., Antonazzo, K.R., Wallgren, M.T., Cortes, R.A. and Thomas, B.F. (2015) ABCHMINACA, AB-PINACA, and FUBIMINA: Affinity and potency of novel synthetic cannabinoids in producing $\Delta^{9}$-tetrahydrocannabinol-like effects in mice. J. Pharmacol. Exp. Ther., 354, 328-339.

29. Cha, H.J., Lee, K., Song, M., Hyeon, Y., Hwang, J., Jang, C., Ahn, J., Jeon, S., Kim, H., Kim, Y., Seong, W., Kang, H., Yoo, H.S. and Jeong, H. (2014) Dependence potential of the synthetic cannabinoids JWH-073, JWH-081, and JWH-210: in vivo and in vitro approaches. Biomol. Ther. (Seoul), 22, 363-369.

30. Roche, J.P., Bounds, S., Brown, S. and Mackie, K. (1999) A mutation in the second transmembrane region of the $\mathrm{CB}_{1}$ receptor selectively disrupts $\mathrm{G}$ protein signaling and prevents receptor internalization. Mol. Cell. Pharmacol., 56, 611-618. 